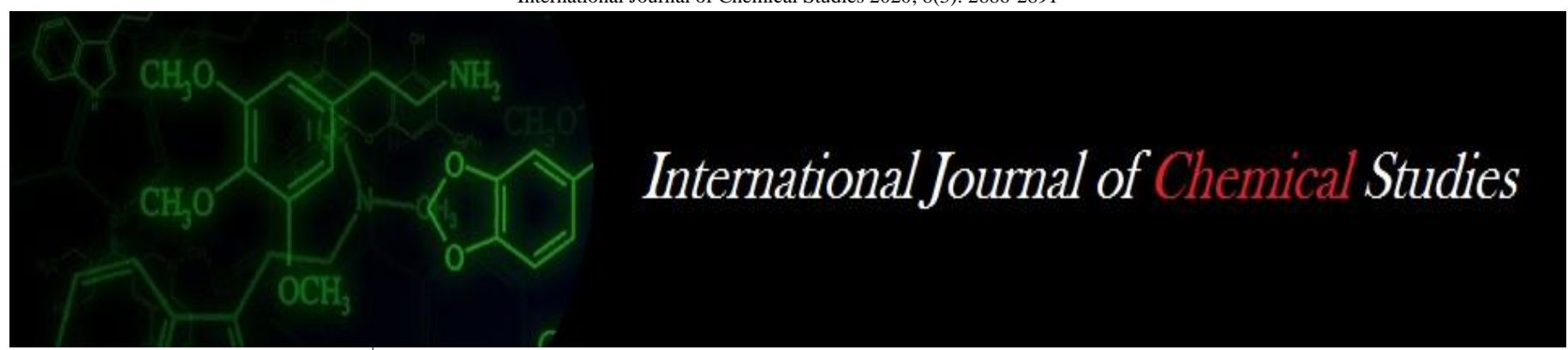

P-ISSN: 2349-8528

E-ISSN: 2321-4902

www.chemijournal.com

IJCS 2020; 8(3): 2886-2891

(C) 2020 IJCS

Received: 13-03-2020

Accepted: 15-04-2020

\section{Dimple Kaparwan}

Department of Agronomy, Sardar Vallabh Bhai Patel

University of Agriculture \& Technology, Meerut, Uttar Pradesh, India

\section{NS Rana}

Department of Agronomy, Sardar Vallabh Bhai Patel University of Agriculture \& Technology, Meerut, Uttar Pradesh, India

Vivek

Department of Agronomy, Sardar Vallabh Bhai Patel University of Agriculture \& Technology, Meerut, Uttar Pradesh, India

\section{BP Dhyani}

Department of Soil Science, Sardar Vallabh Bhai Patel University of Agriculture \& Technology, Meerut, Uttar Pradesh, India

Corresponding Author: Dimple Kaparwan Department of Agronomy, Sardar Vallabh Bhai Patel University of Agriculture \& Technology, Uttar Pradesh, India

\section{Effect of mustard on growth attributes and production of chickpea under varying fertility levels and row ratios in chickpea +mustard intercropping system}

\author{
Dimple Kaparwan, NS Rana, Vivek and BP Dhyani
}

DOI: https://doi.org/10.22271/chemi.2020.v8.i3ap.9650

\section{Abstract}

Most of the developing \& densely populated countries struggle with the major challenge of meeting food $\&$ nutritional requirements for the exponentially rising population. Apart from feeding huge population, our country also faces the issue of land fragmentation which limits the scope of farm automation \& mechanization that plays a key role in cost reduction, optimization of input resources and obtaining higher yields. Therefore, to improve the land use efficiency and obtain higher returns, we are left with the option to intensify crop cultivation during a given cropping season. Chickpea and Mustard are the major rabi season crops which differ in their growth habits and can be grown synergistically with each other in intercropping system. Cultivation of these energy rich crops in rainfed areas is one of the major constraints in achieving their yield potential. Numerous researchers cover the theory and mechanisms of yield stability in intercropping. Willey (1979a) clearly and evidently proposed that intercropping gives higher yields in a given season and greater stability of yields in different seasons compared with sole cropping. However, a little work has been done on chickpea+mustard intercropping system and information related to their comparative performance and sustainability along with beneficial effect of varying levels of inorganic and organic nutrients is lacking, which might be helpful in adopting this intercropping system under resource constraint areas. Keeping the foregoing facts, an investigation was undertaken on "Population Compatibility and Nutrient Management Strategies in Chickpea (Cicer arietinum L.) +Mustard (Brassica juncea L.) Intercropping Systems" at "Sardar Vallabhbhai Patel University of Agriculture and Technology", Meerut (U.P.) during rabi season 2017-18, to optimize planting geometry and devise effective nutrient management strategies. The proposed investigation aims at realizing self-sufficiency in pulses and oilseed production through bridging-up technological gaps. The experimental soil was sandy loam in texture with low available nitrogen $\left(219.3 \mathrm{~kg} \mathrm{ha}^{-1}\right)$, medium in available phosphorus $\left(16.9 \mathrm{~kg} \mathrm{ha}^{-1}\right) \&$ potassium $\left(245.3 \mathrm{~kg} \mathrm{ha}^{-1}\right)$. Twenty treatments consisting of combinations of 04 intercropping systems viz., Chickpea+mustard in 3:1 and 4:1 row ratio and both in additive and replacement series and 05 nutrient management options viz., recommended dose (RD) to chickpea and mustard both $\left(\mathrm{N}_{1}\right), \mathrm{N}_{1}+$ biofertilizers $\left(\mathrm{N}_{2}\right), \mathrm{N}_{2}+\mathrm{FYM}\left(\mathrm{N}_{3}\right), \mathrm{N}_{1}$ but mustard with $150 \%$ RD $\left(\mathrm{N}_{4}\right)$ and $\mathrm{N}_{4}$ with biofertilizers $\left(\mathrm{N}_{5}\right)$ along with sole stand of component crops tested in RBD with 3 replications. Recommended doses were $100 \mathrm{~kg}$ DAP $+20 \mathrm{~kg} \mathrm{~S} \mathrm{ha}^{-1}$ for chickpea and $120 \mathrm{~kg} \mathrm{~N}+40 \mathrm{~kg}$ $\mathrm{P}_{2} \mathrm{O}_{5}+20 \mathrm{~kg}$ S for mustard. Nutrient application to mustard was made as per plant population against sole cropping. Chickpea seeds were inoculated with Rhizobium and mustard with Azotobacter with soil application PSB. The results revealed that chickpea performed individually better in sole stands than intercropping systems. With an exception to plant height, all other growth parameters of chickpea viz., number of branches plant ${ }^{-1}$, dry matter accumulation, number of nodules plant ${ }^{-1}$, dry weight of nodules, grain \& straw yield were maximum in sole chickpea cropping. A reverse trend was however noted in mustard except for plant height. Nutrient management options had significant effect on performance of component crops being best in chickpea with incorporation of FYM + RDF to component crops along with chickpea inoculation with Rhizobium \& mustard inoculation with Azotobacter + soil application of Phosphorous solubilising bacteria.

Keywords: Chickpea + mustard intercropping, additive series, replacement series, nutrient management, rhizobium, azotobacter, phosphorous solubilising bacteria, growth, yield

\section{Introduction}

Food sufficiency for the ever increasing population has been the major concern for developing countries. Despite the achievement of green revolution, still protein and energy malnutrition is 
being observed among the rural masses, which needs to be taken in account as a serious health issue. Apart from the intense population, India also faces the problem of land fragmentation that limits the availability of land area, leaving us with a viable option of crop intensification in time and space. Chickpea is an important pulse crop with high protein content of $20-22 \%$ and its regular intake could alleviate the protein \& energy malnourishment. Being the third most important pulse crop, chickpea constitutes 38 and 45 percent of total pulse area and production in India. On oilseed front, Rapeseed mustard stands second in edible oil production after soybean in India. Growing of Indian mustard as an intercrop with chickpea is a common practice by farmers under limited available resources. In an experiment by Singh et al., (2010), they revealed that intercropping of chickpea with mustard was more beneficial than wheat+mustard intercropping particularly under rainfed conditions. The two crops i.e. chickpea and mustard differs in their competing ability due their differential shoot, root and canopy characteristics. In an intercropping system planting geometry plays a vital role in synthesizing yields and returns as well. Therefore judging appropriate row arrangements in such a way, that a tall plant for high light intensities at top and a compact plant like chickpea for lower intensities at bottom without much shading effect can lead to efficient use of light like a multi-story cropping for obtaining higher yields.

In an intercropping system, nutrient supplementation to plants also plays a key role to increase the crop yields. Though, chemical fertilizers provide essential nutrients that can be easily absorbed and metabolized by plants for optimal growth and development. However, use of chemical fertilizers alone do not provide all the nutrients in balanced quantities needed by plants and cannot meet the total nutrient needs of the modern intensive agriculture. Also, their continued use encourage depletion of soil organic matter, effect physical and biological properties of soil, cause soil health deterioration and soil pollution with increased prices, which has led to renewed interest in the use of organic manures, FYM, vermicompost, bio-fertilizers etc., (Singh, 2010). Use of organic manures not only help to sustain crop yields but also plays a key role by exhibiting both direct as well as indirect influence on the nutrient availability in soil by improving the physical, chemical and biological properties of soil and also improves the fertilizer use efficiency (Singh and Biswas, 2000). Arya et al., (2010) suggested that the application of integrated use of fertilizers along with farm yard manure and bio-fertilizers to chickpea and mustard intercropping not only enhanced the productivity of these crops but also sustainability of the productivity over the years. Therefore an integrated use of nutrients from organic and chemical sources seems to be the need of hour. Bio-fertilizers are low cost, non bulky and environmental friendly agricultural inputs which are used as a supplementary and complementary component for chemical fertilizers, which improve plant nutrition. Dual inoculation with Phosphate solubilizing bacteria (PSB) and Rhizobium strains along with organic manures increase the micro and macro nutrient content in soil under moisture stress conditions. The legume-Rhizobium symbiosis is now the most widely managed agricultural system for biological nitrogen fixation. Inoculation of legumes with exotic strains of Rhizobia is a common agricultural practice intended to promote nitrogen fixation and increase crop yield (Singh, 2010). Use of Nitrogen fertilizers along with Rhizobium inoculation have direct impact on various growth and yield attributes in chickpea. A lot of information is available on cereal + legume intercropping, but not on legume + oilseed system, therefore, the present study was undertaken to assess the effect of cropping system and nutrient management options on growth characteristics \& yields of chickpea under chickpea + mustard intercropping system.

\section{Materials and Methods}

A field experiment was carried out at Sardar Vallabhbhai Patel University of Agriculture and Technology, Meerut (U.P.), during rabi season, 2017-18. The experimental field was well drained, sandy loam in texture and slightly alkaline in reaction. Soil was low in organic carbon \& available nitrogen, whereas medium in available phosphorus \& potassium with electrical conductivity and bulk density of $1.63 \mathrm{dS} / \mathrm{m}$ and $1.36 \mathrm{Mg} / \mathrm{m}^{3}$, respectively. Twenty treatments consisting of 04 intercropping systems viz., Chickpea + mustard in 3:1 and 4:1 row ratio and both in additive and replacement series along with 05 nutrient management options viz., recommended dose (RD) to chickpea and mustard both $\left(\mathrm{N}_{1}\right), \mathrm{N}_{1}+$ biofertilizers $\left(\mathrm{N}_{2}\right), \mathrm{N}_{2}+\mathrm{FYM}\left(\mathrm{N}_{3}\right), \mathrm{N}_{1}$ but mustard with $150 \% \mathrm{RD}\left(\mathrm{N}_{4}\right)$ and $\mathrm{N}_{4}$ with biofertilizers $\left(\mathrm{N}_{5}\right)$ along with sole stand of component crops tested in randomized block design with 3 replications. Recommended doses were $100 \mathrm{~kg}$ DAP $+20 \mathrm{~kg} \mathrm{~S} \mathrm{ha}^{-1}$ for chickpea and $120 \mathrm{~kg}$ $\mathrm{N}+40 \mathrm{~kg} \mathrm{P}_{2} \mathrm{O}_{5}+20 \mathrm{~kg} \mathrm{~S}$ for mustard. Nutrient application to mustard was made as per population against sole stand. Chickpea seeds were inoculated with Rhizobium and mustard with Azotobacter while PSB was soil applied. Chickpea variety BGM 547 and mustard variety Kranti were sown on $25^{\text {th }}$ of October 2017 and harvested on $14^{\text {th }}$ of March and $30^{\text {th }}$ of April 2018, respectively. Seeds were sown manually in line at a depth of $8 \mathrm{~cm}$ for chickpea and $4 \mathrm{~cm}$ for mustard. The row to row and plant to plant spacing for chickpea was $30 \mathrm{~cm}$ and $15 \mathrm{~cm}$ while in case of mustard the spacing varied according to intercropping situations. Irrigation was provided as per need of crop. Crop were kept weed free by regular hand weeding. Observations on growth attributes of chickpea viz., plant height, number of branches plant ${ }^{-1} \&$ dry matter accumulation were taken at 30,60,90 120 DAS till harvest while number of nodules and dry weight of nodules at 60,90 and 120 DAS. Grain yield, straw yield and biological yield were recorded post harvest of chickpea. Grain and straw yield were estimated based on produce obtained from the net plot area of each treatment.

\section{Discussion and Results \\ 3.1 Growth Parameters \\ 3.1.1 Plant height $(\mathrm{cm})$}

Plant height in chickpea varied significantly under different intercropping treatments at all the crop growth stages. Plant height increased with advancing crop age upto 120 days stage. In general, the plants were taller in intercropping situations than in sole cropping. Among the intercropping systems, tallest plants of chickpea were measured when chickpea grown with mustard in 4:1 additive series which was at par with respective $3: 1$ and significantly superior to respective 3:1 and $4: 1$ replacement series at all the growth stages. Shading effect of mustard on chickpea was more pronounced in additive series which might have caused chickpea to grow tall in search of light for better growth and development. Among different nutrient management options, application of RDF in chickpea treated with Rhizobium + RDF in mustard treated with Azotobacter + FYM + PSB as soil applied, resulted in tallest plants while shorter plants in chickpea were noted with application of recommended dose of fertilizer to chickpea and 
mustard irrespective of the growth stages. Similar results were given by Ahlawat et al., (2005) ${ }^{[2]}$, they revealed that chickpea attained more plant height in intercropping with mustard, due competition posed by mustard on chickpea for available resources (light and space) resulting in taller plants of chickpea. Similar findings were also reported by Thakur et al., (2000) ${ }^{[16]}$ and Tripathi et al., (2005) ${ }^{[14,15]}$.

\subsubsection{Number of branches plant ${ }^{-1}$}

Inclusion of mustard as intercrop with chickpea had pronounced effect on number of branches plant ${ }^{-1}$ at all the stages of growth with highest increment in branches between 60 to 90 days period. Sole chickpea recorded highest number of branches due to less competition for available resources (water, nutrients, space and light). Among intercropping treatments, chickpea grown with mustard in 4:1 replacement series produced more number of branches plant ${ }^{-1}$ than chickpea+ mustard 3:1 and 4:1 additive series at all growth stages. This might be due to lesser plant population in chickpea + mustard replacement series which promoted more growth in horizontal direction, hence more number of branches obtained. Also, in replacement series, competition between chickpea and mustard for available resources is low in comparison to additive series which have dense plant population and greater competition for resources. With regard to nutrient management options, chickpea had profuse branching with incorporation of farm yard manure + RDF in chickpea treated with Rhizobium $+\mathrm{RDF}$ in mustard treated with Azotobacter + soil application of PSB. Similar findings were observed by Kushwaha and De (1987) ${ }^{[7]}$, they revealed that number of branches, pods, seed yield plant ${ }^{-1}$ and 1000seed weight of chickpea decreased in chickpea + mustard intercropping system than sole chickpea.

\subsubsection{Dry matter accumulation $\left(\mathrm{g}^{-1} 0.5 \mathrm{~m}\right.$ row length)}

Dry matter accumulation in chickpea increased with advancement in crop age and was found significant at all stages of crop growth. Due to better utilization of available resources sole chickpea recorded maximum dry matter against all intercropping treatments. Among the intercropping situations, chickpea +mustard 4:1 replacement series recorded highest accumulation of dry matter, which was at par with respective 3:1 replacement series and significantly superior over chickpea + mustard 3:1 and 4:1 additive series at all stages. This might be due to higher competition for available resources because of more plant population in additives series than chickpea +mustard replacement series which had lesser plant population of component crops, posing low competition for light, water, space and nutrients. Among different nutrient management options, lowest accumulation of dry matter was recorded when component crops were fed with recommended doses of fertilizer. Maximum dry matter was observed in sole chickpea against all nutrient management options, followed by RDF in chickpea inoculated with Rhizobium + RDF in mustard inoculated with Azotobacter + FYM +PSB as soil applied which was at par with $100 \%$ RDF in chickpea inoculated with Rhizobium $+150 \%$ RDF in mustard inoculated with Azotobacter +PSB as soil applied.

\subsubsection{Number of nodules plant ${ }^{-1}$}

Intercropping significantly influenced the number of nodules plant $^{-1}$ at all growth stages of chickpea. Sole crop of chickpea recorded maximum number of nodules plant $^{-1}$ which was significantly higher against all row ratios of chickpea +mustard intercropping systems. Among intercropping systems, maximum number of nodules plant ${ }^{-1}$ was recorded at 90 days stage, in chickpea grown with mustard under 4:1 replacement series which was significantly superior over when chickpea +mustard 3:1 and 4:1 additive series. After 90 days stage a decline in nodules was observed due to utilization of nodule nitrogen by chickpea. Chickpea requires only a starter dose of nitrogen for early growth while remaining nitrogen is provided through atmospheric nitrogen fixation in root nodules by Rhizobium bacteria. Chickpea roots development was restricted due to proliferation of vigorous roots of mustard which made a negative impact on nodule formation in chickpea under intercropping system whereas under sole chickpea crop, lesser competition for root growth was observed which provided conducive environment for better root development. Variation in number of nodules plant $^{-1}$ was found to be non significant among all nutrient management options. Sole crop of chickpea recorded significantly higher number of nodules plant ${ }^{-1}$ against all nutrient management options. Among nutrient management treatments, maximum number of nodules plant ${ }^{-1}$ was recorded when given RDF in Rhizobium treated chickpea + RDF in mustard treated with Azotobacter + FYM + PSB. This could be possibly due to addition of FYM which enhances the soil fertility, microbial population, aeration and water holding capacity making soil conditions more conducive for multiplication of phosphorous solubilising bacteria in soil, ultimately leading to increase in phosphorous content in soil required for vigorous root growth and better nodule formation.

\subsubsection{Dry weight of nodules plant ${ }^{-1}\left(\mathrm{mg} \mathrm{plant}^{-1}\right)$}

Dry weight of nodules exhibited significant variation among intercropping situations. Sole chickpea recorded highest dry weight of root nodules followed by chickpea +mustard $4: 1$, $3: 1$ replacement series, thereafter chickpea +mustard 4:1, 3:1 additive series. Effect of nutrient management options was non-significant on dry weight of nodules. Compared to nutrient management options, sole crop of chickpea recorded highest dry weight of nodules plant ${ }^{-1}$ at all stages of growth. Among different nutrient management strategies, maximum dry weight of nodules plant ${ }^{-1}$ was recorded when the component crops were given RDF in chickpea inoculated with Rhizobium + RDF in mustard with Azotobacter + FYM + PSB which was at par with nutrient management option of $150 \%$ RDF in mustard treated with Azotobacter $+100 \%$ RDF in chickpea + Rhizobium inoculation + PSB. It could be possibly due to soil application of FYM and PSB, which led to increased available phosphorous and micro nutrients content in soil to promote better nodule formation. Similar results were given by Tripathi et al. (2005) ${ }^{[14,15]}$ and Arya et al., (2007) ${ }^{[3,12]}$. 


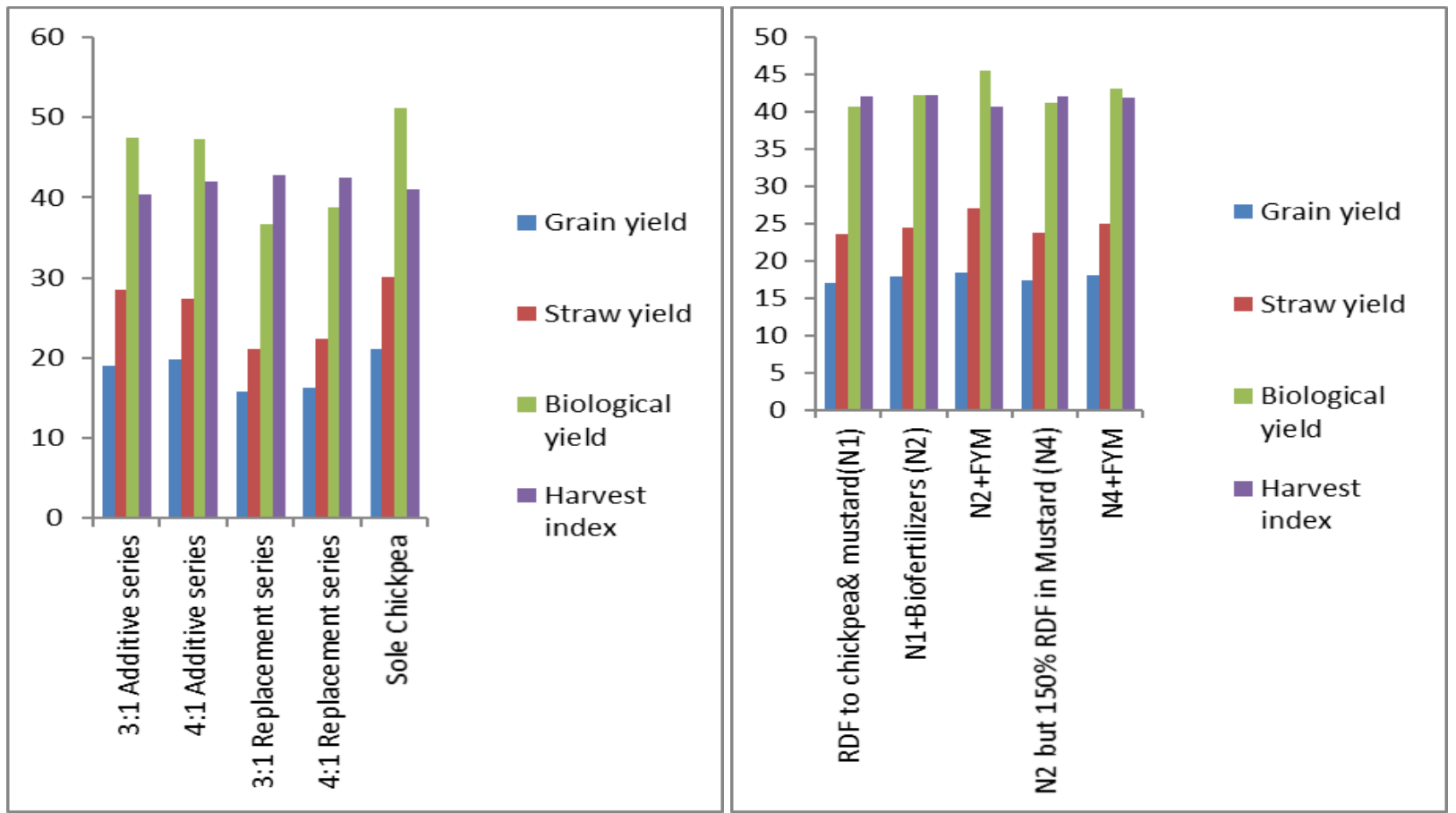

Fig 1, 2: Effect of cropping system and nutrient management options on grain yield, straw yield, biological yield and harvest index of chickpea

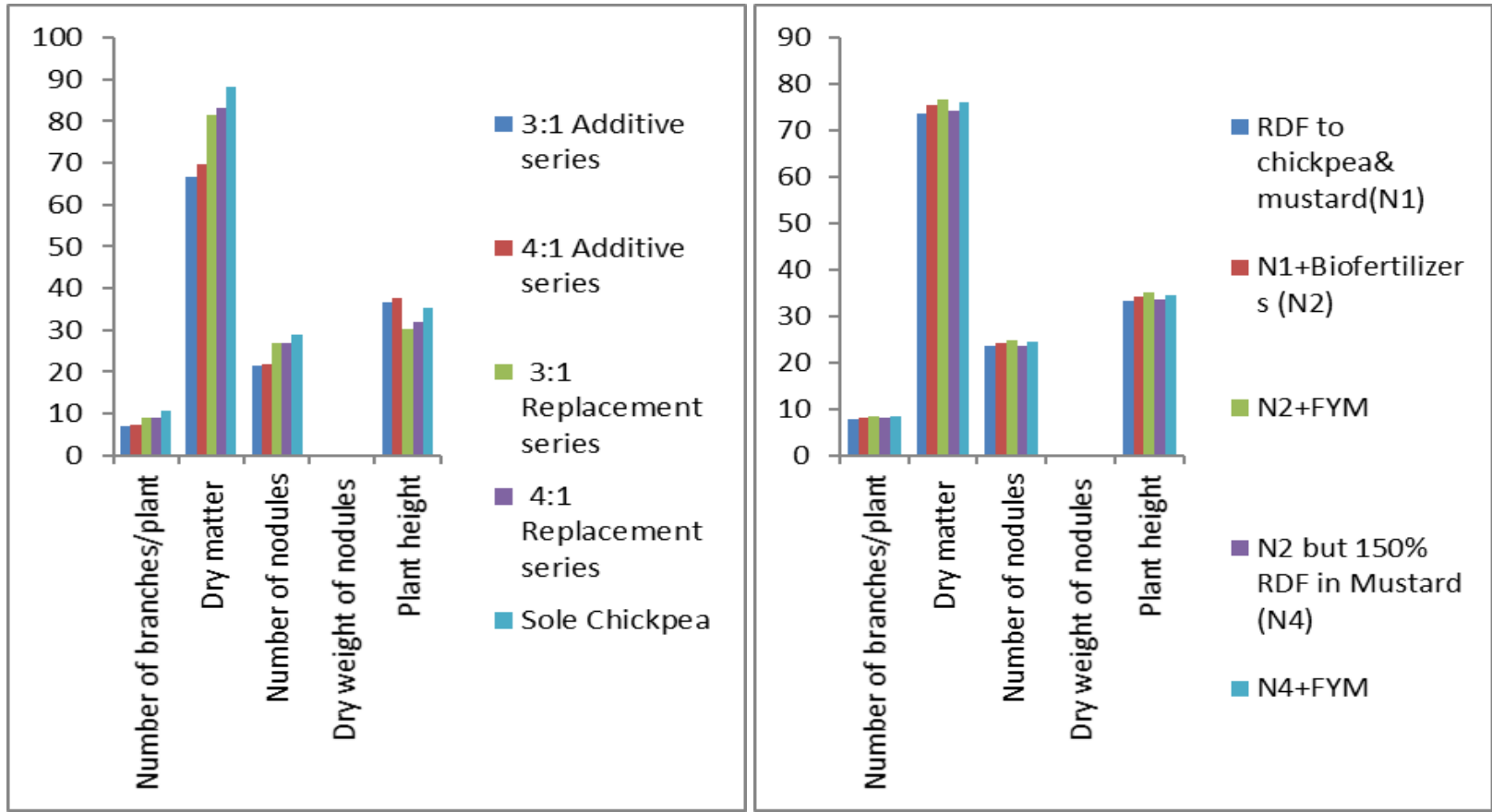

Fig $3 \&$ 4: Effect of cropping system and nutrient management options on plant height, dry matter, number of branches, number of nodules and dry weight of nodules in chickpea.

\subsection{Yield}

\subsubsection{Grain yield $\left(\mathbf{q} \mathbf{h a}^{-1}\right)$}

Intercropping treatments and nutrient management options significantly affected the grain yield of chickpea. Sole chickpea produced maximum grain yield over all intercropping situations. Highest grain yield among intercropping ratios was found in chickpea +mustard 4:1 additive series which was at par with respective $3: 1$ additive series and superior over chickpea +mustard 3:1 and 4:1 replacement series. Moreover, when compared to different nutrient management options, maximum grain yield was observed in sole chickpea followed by nutrient management option of RDF in chickpea inoculated with Rhizobium + RDF in mustard inoculated with Azotobacter $+\mathrm{FYM}+\mathrm{PSB}$ as soil applied, which was at par with nutrient dose of $100 \%$ RDF in chickpea treated with Rhizobium $+150 \%$ RDF in mustard with Azotobacter + PSB. Similar results were given by Punia et al., (1999), they observed the adverse effect of mustard on chickpea in intercropping situations, where $83.3 \%$ rows of chickpea yielded $79.4 \%$ grain yield incurring a loss of $3.9 \%$ in chickpea yield due to mustard. Similarly, Prasad et al., (2003) reported from Kanpur that $80 \%$ population of chickpea in intercropping with mustard varieties, produced grain yield of $70 \%$ to $79.3 \%$ which stand the losses of 0.7 to $9.9 \%$ in chickpea yield due to mustard varieties. Also, Singh (2004) reported yield reduction of chickpea from 2.18 to $12.95 \%$ due to intercropping of different varieties of mustard. In similar lines, Tripathi et al., (2005) ${ }^{[14,15]}$ reported from Kanpur, U.P. that seed yield of chickpea with mustard in 8:2 row ratio reduced by $28.3 \%$ compared with sole crop of chickpea. 


\subsubsection{Straw yield (q ha $\left.\mathbf{~ h}^{-1}\right)$}

Intercropping system and nutrient management options exhibited significant influence on straw yield of chickpea. Sole chickpea produced largest quantity of straw against all intercropping treatments. Among intercropping situations, chickpea + mustard 4:1 additive series recorded highest straw yield which was at par with respective 3:1 additive and superior over chickpea + mustard 3:1, 4:1 replacement series. It could be possibly due to less competition for sunlight, space, water and nutrients in sole crop of chickpea as compared to intercropping treatments wherein the competition between component crops might have restricted efficient utilization of resources and therefore growth of chickpea was lesser from initial stage till harvest. When compared between additive and replacement series, significantly higher grain and straw yield of chickpea was obtained in additive series mainly because of higher plant population. Similar results were revealed by Tripathi et al., (2005) ${ }^{[14,15]}$ and Kumar and Singh (2006) [6]. Among different nutrient management options, lesser straw yield was recorded in comparison to sole chickpea followed by nutrient management option of RDF in chickpea treated with Rhizobium and mustard treated with Azotobacter + FYM + PSB, while lowest was obtained with $\mathrm{RDF}$ to component crops. This finding is in conformity with the results of Dhingra et al. (1990) [4], Kumar and Nandan (2007) ${ }^{[5]}$, Tripathi et al. (2005b) ${ }^{[15]}$ and Thakur et al. (2000) [16].

\subsubsection{Biological yield ( $\mathrm{q} \mathrm{ha}^{-1}$ )}

Biological yield of chickpea was significantly affected by intercropping system and nutrient management options. Sole chickpea recorded highest biological yield in comparison to intercropping treatments. Among different intercropping situations, maximum biological yield was obtained in chickpea +mustard 3:1 additive series which was at par with respective $4: 1$ additive series followed by chickpea +mustard 4:1 replacement series than 3:1 replacement series. Also, less biological yield was recorded with all nutrient management options in comparison to sole cropping of chickpea. Among different nutrient management options, highest biological yield was obtained with RDF in chickpea treated with Rhizobium + RDF in mustard treated with Azotobacter + FYM + PSB as soil applied, which was at par with nutrient dose of $150 \%$ RDF in mustard treated with Azotobacter + $100 \%$ RDF in chickpea treated with Rhizobium + PSB and superior over rest of the nutrient combinations.

\subsubsection{Harvest index}

Intercropping system and nutrient management options significantly influenced the harvest index of chickpea. Higher value of harvest index was obtained in intercropping against sole crop of chickpea. Maximum value of harvest index was recorded in chickpea + mustard 3:1 replacement series which was superior to sole chickpea and other intercropping situations. Among different nutrient management options, highest value of harvest index was recorded with nutrient dose of RDF in mustard treated with Azotobacter + RDF in chickpea treated with Rhizobium + PSB, which was significantly superior over sole chickpea and all other nutrient management options.

\section{Conclusion}

Based on above results it can be concluded that except plant height all other growth parameters of chickpea viz., number of branches, dry matter accumulation, number and dry weight of nodules, grain yield and straw yield were maximum in sole cropping. A reverse trend was however noted in mustard except for plant height. Similar findings in chickpea + mustard intercropping have also been reported by Tripathi et al. (2005) ${ }^{[14,15]}$ and Kumar and Singh (2006) ${ }^{[6]}$. Nutrient management options also had significant effect on performance of component crops being best in chickpea with incorporation of FYM + RDF to component crops along with chickpea treatment with Rhizobium \& mustard treatment with Azotobacter + soil application of Phosphorous solubilising bacteria. Consequently, further research is needed to explore more diversified intercropping systems for better know how of crop compatibility in different row ratios under various nutrient management strategies to enhance the land use efficiency and crop production.

Table 1: Effect of intercropping treatments and nutrient management options on growth attributes of chickpea

\begin{tabular}{|c|c|c|c|c|c|c|}
\hline \multirow{2}{*}{\multicolumn{2}{|c|}{ Treatments }} & \begin{tabular}{|c|} 
Plant \\
height $(\mathrm{cm})$
\end{tabular} & $\begin{array}{c}\text { Number of } \\
\text { branches plant }^{-1}\end{array}$ & \begin{tabular}{|c|} 
Dry matter $\left(\mathrm{g}^{-1} \mathrm{0.5} \mathrm{m}\right.$ \\
row length $)$
\end{tabular} & $\begin{array}{c}\text { Number of } \\
\text { nodules }\end{array}$ & $\begin{array}{c}\text { Dry weight of nodules } \\
\left(\text { mg plant }^{-1}\right)\end{array}$ \\
\hline & & \multicolumn{3}{|c|}{ At harvest } & \multicolumn{2}{|r|}{120 days } \\
\hline \multicolumn{2}{|c|}{ Sole chickpea } & 35.27 & 10.75 & 88.20 & 29.00 & 0.277 \\
\hline \multicolumn{7}{|c|}{ Cropping system } \\
\hline \multicolumn{2}{|c|}{ Chickpea + mustard (3:1 A) } & 36.62 & 6.91 & 66.57 & 21.33 & 0.17 \\
\hline \multicolumn{2}{|c|}{ Chickpea + mustard (4:1 A) } & 37.75 & 7.37 & 69.74 & 21.71 & 0.18 \\
\hline \multicolumn{2}{|c|}{ Chickpea + mustard (3:1 R) } & 30.15 & 9.07 & 81.49 & 26.74 & 0.22 \\
\hline \multicolumn{2}{|c|}{ Chickpea + mustard (4:1 R) } & 31.85 & 9.12 & 83.18 & 26.85 & 0.23 \\
\hline \multicolumn{2}{|c|}{ S.Em. \pm} & 0.84 & 0.17 & 1.67 & 0.54 & 0.003 \\
\hline \multicolumn{2}{|c|}{$\mathrm{CD}(\mathrm{P}=0.05)$} & 2.4 & 0.49 & 4.78 & 1.55 & 0.009 \\
\hline \multicolumn{7}{|c|}{ Nutrient Management Options } \\
\hline \multicolumn{7}{|l|}{ Chickpea } \\
\hline RDF & RDF & 33.35 & 7.83 & 73.76 & 23.51 & 0.19 \\
\hline RDF + Rhizo. & RDF + Azoto. & 3416 & 813 & 7539 & 2427 & מ 02 \\
\hline \multicolumn{2}{|c|}{ PSB } & & 8.13 & 15.39 & 24.21 & 0.20 \\
\hline RDF + Rhizo. & RDF + Azoto. & 3496 & 8.43 & 7679 & 2486 & 020 \\
\hline \multicolumn{2}{|c|}{ PSB +FYM } & 34.96 & 8.43 & 10.19 & & \\
\hline RDF & $150 \% \mathrm{RDF}$ & 33.58 & 7.95 & 74.35 & 23.70 & 0.19 \\
\hline RDF + Rhizo. & $150 \%$ RDF + Azoto. & 34.42 & 8.25 & 75.94 & 24.44 & 0.20 \\
\hline \multicolumn{2}{|r|}{ PSB } & 0.94 & 0.19 & 187 & 0.60 & 0.004 \\
\hline \multicolumn{2}{|c|}{$\mathrm{CD}(\mathrm{P}=0.05)$} & NS & NS & NS & NS & NS \\
\hline
\end{tabular}


Table 2: Effect of intercropping treatments and nutrient management options on yields and harvest index of chickpea



\section{References}

1. Abraham T, Thenua OVS, Sharma UC. Evaluation performance of chickpea and mustard intercropping system viz.-a-viz. their sole crops as influenced by irrigation regimes and fertility gradients. Indian Journal of Agricultural Sciences. 2011; 81(8):772-775.

2. Ahlawat IPS, Gangaiah B, Singh O. Production potential of chickpea (Cicer arietinum) based intercropping systems under irrigated condition. Indian Journal of Agronomy. 2005a; 50(1):27-30.

3. Arya RL, Varshney JG, Kumar L. Effect on integrated nutrient application in chickpea + mustard intercropping systems in the semi-arid tropics of North India. Soil Science and Plant Analysis. 2007; 38(1, 2):229-240.

4. Dhingra KK, Grewal DS, Dhillon MS. Competitive ability of raya and chickpea in different intercropping pattern and row directions. International Journal of Tropical Agriculture. 1990; 8(4):282-8.

5. Kumar G, Nandan R. Effect of date and pattern of planning on productivity and economics of chickpea + mustard intercropping system. Journal of food legumes 2007; 20(92):184-186.

6. Kumar A, Singh BP. Effect of row ratio and phosphorus level on performance of chickpea (Cicer arietinum) + Indian mustard (Brassica juncea) intercropping. Indian Journal of Agronomy. 2006; 51(2):100-102.

7. Kushwaha BL, De R. Studies of resource use and yield of mustard and chickpea grown in intercropping systems. Journal of Agricultural Science Cambridge. 1987; 108:487-495.

8. Varshney GJ, Arya RL. Effect of integrated nutrients use and weedcontrol methods on sole gram (Cicer arietinum) and gram + Indian mustard (Brassica juncea) intercropping system. Indian Journal of Agricultural Sciences. 2004; 74(3):121-125.

9. Patra B, Poi SC. Influence of intercropping on nodulation in legumes. Environment and Ecology. 1998; 16(2):418423.

10. Punia SS, Singh BP, Kumar S. Production potential and returns of mustard (Brassica juncea) intercropping system under rainfed condition of Haryana. Indian Journal of Agronomy. 1998; 44(3):514-517.
11. Rana KS, Pal M, Kumar P, Pal M, Kumar P. Studies on fertilization under dry land conditions. Annals of Agricultural Research. 1996; 17(3):305-307.

12. Arya RL, Varshney JG, K. Lalit Effect of integrated nutrient application in chickpea + mustard intercropping system in semi arid tropics of North India Commun. Soil Sci. Plant Anal. 2007; 38(2):229-230

13. Singh KK, Rathi KS. Dry matter production and productivity as influenced by staggered sowing of mustard intercropped at different row ratios with Chickpea. Journal of Agronomy and Crop Science. 2003; 189(3):169-175.

14. Tripathi HN, Chand S, Tripathi AK. Biological and economical feasibility of chickpea (Cicer arientinum) + Indian mustard (Brassica juncea) cropping systems under varying levels of phosphorus. Indian Journal of Agronomy. 2005a; 50(1):31-34.

15. Tripathi HN, Chand S, Tripathi AK. Growth and yield of Bengal gram (Cicer arientinum) as influenced by mustard raised as intercrop and varying levels of phosphorus. Research on Crops. 2005b; 6(2):205-208.

16. Thakur NS, Pannase SK, Sharma RS. Production potential of gram (Cicer arietinum)-based intercropping system under rainfed condition. Indian Journal of Agronomy. 2000; 45(3):534-539.

17. Willey RW. Intercropping: Its importance and research needs, part I: Competition and yield advantages. Field Crop Abstract. 1979a; 32:1-10. 